\title{
Rancang Bangun dan UJi Kinerja Prototipe Mesin Perontok Sorgum
}

\author{
Designing And Performace Test The Prototype Of Sorghum Thresher Machine
}

\author{
Asep Yusuf ${ }^{1)}$, Sudaryanto ${ }^{1)}$ dan Wahyu K. Sugandi ${ }^{1)}$ \\ ${ }^{1)}$ Departemen Teknik Pertanian dan Biosistem, FTIP, Universitas Padjadjaran \\ Jalan Raya Bandung-Sumedang Km 21, Jatinangor 40600 \\ Email : asyefa@gmail.com
}

\begin{abstract}
ABSTRAK
Selama ini, hasil penyosohan biji sorgum menggunakan mesin penyosoh biji sorgum masih meninggalkan masalah berupa kulit biji yang ikut terolah, sehingga setelah proses penyosohan selesai perlu dilakukan proses pemisahan kulit biji dari biji sorgum hasil penyosohan. Tujuan dari penelitian ini yaitu merancang bangun prototipe Mesin Perontok Sorgum untuk menghasilkan biji sorgum yang bersih dan siap disosoh. Metode penelitian yang digunakan adalah metode rekayasa, yaitu kegiatan merancang bangun mesin perontok sorgum. Mesin perontok sorgum berhasil dirancang bangun dengan komponen utama terdiri dari: hopper, rangka, blower, ruang perontokkan, motor penggerak, saluran pengeluaran kotoran, saluran pengeluaran malai, saluran pengeluaran biji dan roda. Spesifikasi mesin yaitu panjang $160 \mathrm{~cm}$, lebar $95 \mathrm{~cm}$, tinggi $124 \mathrm{~cm}$, kapasiatas aktual mesin yaitu 151,84 kg/jam dan penggeraknya motor diesel $8 \mathrm{HP}$. Data hasil pengujian mesin perontok beban isi yaitu kecepatan putar silinder $636 \mathrm{rpm}$, kecepan aliran udara 3,4 m/detik dan tingkat kebisingan 94,6 dB.
\end{abstract}

Kata Kunci : Rancang Bangun, Mesin Perontok sorgum, Sorgum

\begin{abstract}
Sorghum milling machine that used nowdays has several problems caused by the seed coat of the sorghum grain that included in the milling process. So that after the milling process is complete, it is require to sparating the seed coat of the sorghum from the milling product. The aim of this research is to design a prototype of sorghum thresher machie that produce grain sorghum, which were clean from the seed coat and ready to be polished. Method that used in this research was the method of engineering, while the activities is to design a sorghum thesher machine. Sorghum thresher machine was successfully designed and build by the main components of hopper, frame, blower, thresher space, engine, dirt channel expenditure, panicle channel expenditure, seed channel expenditure and whell. The specification of the machine are $160 \mathrm{~cm}$ of length, $95 \mathrm{~cm}$ of width, $124 \mathrm{~cm}$ of height, and $151.84 \mathrm{~kg} / \mathrm{h}$ of actual capacity. The machine was driven by a $8 \mathrm{HP}$ of diesel engine. The result show that the machine works in $636 \mathrm{rpm}$ ofcylinder rotary speed, $3.4 \mathrm{~m} / \mathrm{sec}$ of airflow speed, and $94.6 \mathrm{~dB}$ of noise level in the condition when the machine is loaded.
\end{abstract}

Keywowd: Design, Sorghum thresher machine, sorghum

Diterima : 26 Mei 2016; Disetujui : 15 Agustus 2016 ; Online Published : 31 Oktober 2016

\section{PENDAHULUAN}

Permasalahan pangan di Indonesia terutama bahan makanan pokok, tidak akan pernah terlepas dari masalah beras dan terigu, disamping bahan pangan lainnya seperti ubi kayu, jagung, dan sagu (Colas, 1994). Upaya untuk meningkatkan produksi beras sebagai bahan makanan pokok masyarakat Indonesia bukanlah hal mudah, karena banyak terjadi pengalihan fungsi lahan pertanian berupa sawah, secara massal menjadi area pemukiman dan 
industri. Disisi lain, produksi gandum dunia terus menurun disebabkan salah satunya oleh cuaca ekstrem di sentra-sentra produksi gandum pada tahun 2010. Hal ini berdampak pada stok gandum dunia terus menipis pada tahun 2011, yang berujung pada kenaikan harga gandum dunia (Suhendra, 2011). Oleh karena itu, upaya pengembangan pangan alternatif yang berbasis umbi-umbian, tanaman pohon atau biji-bijian, menjadi sangat penting guna mendukung Ketahanan Pangan. Menurut Colas (1994) salah satu alternatif pemecahan masalah kelangkaan bahan pangan, terutama makanan pokok penghasil karbohidrat adalah melalui subsitusi dengan sorgum. Sorgum dapat diproses menjadi tepung yang bisa diolah menjadi aneka produk makanan yang mempunyai nilai tambah tinggi.

Sorgum merupakan serealia sumber karbohidrat dengan nilai gizi cukup memadai sebagai bahan pangan. Kandungan gizi sorgum yaitu: $83 \%$ karbohidrat, 3,5\% lemak dan $10 \%$ protein (basis kering). Sorgum dapat digunakan sebagai bahan pangan, pakan dan sumber energi biofuel. Sayangnya, pemanfaatan sorgum sebagai bahan pangan di Indonesia masih sangat terbatas (Suarni 2004). Pemanfaatan sorgum sebagai bahan pangan masih menemui kendala dalam hal kandungan tanin yang terdapat pada lapisan kulit ari biji (lapisan testa) yang bersifat sebagai senyawa anti-nutrisi. Kandungan senyawa anti-nutrisi dan kulit biji menyebabkan rasa sepat dan sulit untuk dicerna. Kadar tanin dalam biji sorgum berkisar antara $0,4-3,6 \%$. Penyosohan yang tidak sempurna menyebabkan warna tepung yang dihasilkan agak gelap (sebagian kulit masih tersisa), tekstur kasar, serta hasil olahannya terasa sepat (Mudjisihono, 1987).

Kandungan tanin pada biji sorgum dapat diatasi salah satunya dengan cara disosoh. Pada penelitian sebelumnya, Mmesin penyosoh Sorgum TEP-3 telah menghasilkan rendemen diatas $80 \%$ dengan warna sosohan yang bersih (Yusuf dkk, 2011). Mesin Penyosoh Sorgum TEP-3 masih memiliki beberapa kekurangan salah satunya masih harus dilakukan pemisahan kulit sorgum dari biji sorgum yang telah disosoh. Adanya kulit biji yang masih ikut terolah pada saat proses penyosohan disebabkan oleh proses perontokan yang kurang baik. Oleh karena itu perlu untuk melakukan rancang bangun mesin perontok sorgum sehingga dihasilkan biji sorgum yang bersih dan siap disosoh.

Tujuan penelitian ini adalah untuk melakukan rancang bangun prototipe Mesin Perontok Sorgum yang menghasilkan biji sorgum yang siap sosoh dan bersih dari kulit biji.

\section{METODE PENELITIAN}

\section{Tempat dan Waktu Penelitian}

Mesin penyosoh sorgum dikerjakan di Bengkel Logam, Jurusan Teknik dan Manajemen Industri Pertanian, Fakultas Teknologi Industri Pertanian Unpad. Mulai April 2012 hingga November 2012.

\section{Bahan dan Peralatan}

Bahan yang digunakan dalam penelitian ini adalah biji sorgum lokal Bandung. Pada tahap rancang bangun, peralatan yang digunakan adalah peralatan bengkel seperti: mesin bubut, mesin frais, mesin las, alat potong plat, alat lipat plat, gerinda potong, kompresor, alat mengecat, dll. Pada tahap pengujian mesin peralatan yang digunakan yaitu: tachometer, soundlevel, timbangan analog, timbangan digital, stopwatch, kalkulator, seperangkat komputer (pc).

\section{Tahapan Penelitian}

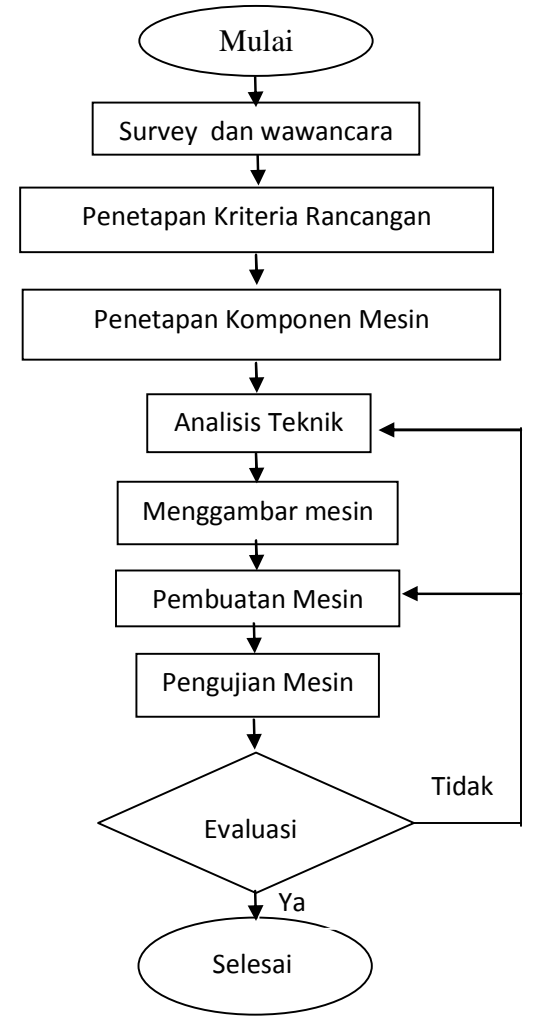

Gambar 1. Tahapan Metode Penelitian 
Berdasarkan tahapan penelitian pada Gambar 1, maka dapat dijelaskan pelaksanaan penelitian sebagai berikut:

1). Survey dan wawancara

Survey dan wawancara bertujuan untuk mengetahui cara dan peralatan yang biasa digunakan petani untuk merontokan sorgum. Juga untuk mengetahui kapasitas mesin yang diperlukan.

2). Penetapan Kriteria Rancangan

Kriteria rancangan mesin bertujuan untuk menetapkan apa yang diharapkan dari mesin yang akan dibuat. Penetapan kriteria mesin merupakan masukkan dari survey kebutuhan. Selain itu, hasil survey menjadi masukkan dalam pembuatan gambar mesin, yaitu: kapasitas mesin, bentuk dan ukuran dari komponen mesin, daya yang dibutuhkan dan mekanisme perontokan.

3). Penetapan Komponen Mesin

Penetapan komponen mesin didasarkan dari hasil pengamatan proses perontokan.

4). Analisis Teknik

Analisis teknik adalah proses menghitung secara matematik kekuatan bahan dan perancangan mesin yang berhubungan dengan ukuran, gaya-gaya yang bekerja dan umur dari beberapa elemen mesin yang digunakan pada mesin perontok sorgum.

5). Pembuatan Gambar Mesin

Pembuatan gambar mesin didasarkan pada kriteria rancangan mesin yang telah ditetapkan. Pada kegiatan menggambar ada dua proses yang harus dikerjakan secara simultan, yaitu: analisis teknik dan menggambar. Analisis teknik adalah menghitung secara matematis beberapa komponen mesin yang digunakan dengan mengunakan data-data standar atau hasil pengukuran secara langsung. Proses menggambar merupakan visualisasi dari proses analisis teknik sehingga dihasilkan gambar yang mencerminkan bentuk mesin sesungguhnya yang akan dibuat.

6). Pembuatan Mesin

Pembuatan mesin berdasarkan gambar mesin, baik bentuk maupun ukurannya di bengkel teknik.

7). Pengujian Mesin

Pengujian mesin dilakukan setelah mesin perontok sorgum selesai dibuat. Pada pengujian dilakukan pengamatan dan pengukuran, yaitu: kinerja mesin, kapasitas mesin, kebersihan hasil perontokan dan daya aktual mesin.

\section{HASIL DAN PEMBAHASAN}

\section{Perancangan Mesin Perontok Sorgum}

Perancangan mesin perontok sorgum didasarkan pada tahapan penelitian, dengan rincian sebagai berikut :

\section{1). Survey Kebutuhan}

Survey Kebutuhan bertujuan untuk mengetahui cara dan peralatan yang biasa digunakan petani untuk merontokan sorgum. Selain itu mengetahui kapasitas mesin yang diperlukan. Survey telah dilakukan ke Kelompok Tani Harapan Sejahtera, yang sedang mengembangkan tanaman sorgum, mulai dari budidaya sampai pada olahannya. Kelompok Tani ini berlokasi di Desa Bojongmanggu Kecamatan Pameungpeuk, Kabupaten Bandung. Dari hasil wawancara diperoleh informasi bahwa perontokkan sorgum dilakukan secara manual kemudian dibersihkan dengan mesin pemecah kulit padi (huler) dan ada juga yang menggunakan mesin perontok padi. Sorgum hasil perontokan manual yang dihasilkan oleh Kelompok Tani Harapan Sejahtera, diuji untuk dilihat hasil sosohannya, penyosohan menggunakan sorgum hasil perontokkan yang telah dilakukan ternyata hasil sosohan masih belum baik karena hasil perontokkan yang kurang bersih. Kulit sorgum sifatnya ringan sehingga pada saat disosoh kulit sorgum akan melayang dan tidak hancur pada saat disosoh. Kulit ini bercampur dengan biji sorgum hasil sosohan, sehingga perlu dipisahkan lagi dari biji sorgum hasil penyosohan.

\section{2). Identifikasi Mesin Perontok Sorgum}

Identifikasi bertujuan untuk mengetahui karakteristik mesin yang diperlukan untuk merontokan biji sorgum dari malainya. Berdasarkan hasil survey kebutuhan dan pengujian penyosohan, maka dapat diidentifikasi masalahnya yaitu perlunya dirancang bangun mesin perontok sorgum untuk menghasilkan biji sorgum yang bersih dan siap disosoh. 


\section{3). Penetapan Kriteria Rancangan}

Kriteria rancangan mesin bertujuan untuk menetapkan apa yang diharapkan dari mesin yang akan dibuat. Penetapan kriteria mesin merupakan masukkan dari survey kebutuhan. Selain itu, hasil survey menjadi masukkan dalam pembuatan gambar mesin, yaitu: kapasitas mesin, mekanisme perontokan, motor penggerak yang digunakan dan kualitas hasil yang diharapkan. Dengan demikian, kriteria mesin perontok sorgum adalah sebagai berikut:

a. Kapasitas perontokkan $100 \mathrm{~kg} / \mathrm{jam}$

b. Sistem pengumpanan malai adalah sistem throw in yaitu malai dimasukkan ke ruang perontokan.

c. Motor Penggerak menggunakan motor diesel

d. Adanya blower untuk menghembus kulit dan kotoran yang bercampur bada biji sorgum

\section{4). Analisis Teknik}

Analisis teknik adalah proses menghitung secara matematik kekuatan bahan dan perancangan mesin yang berhubungan dengan ukuran, gaya-gaya yang bekerja dan umur dari beberapa elemen mesin yang digunakan pada mesin perontok sorgum. Analisis teknik yang dilakukan meliputi: kapasitas teoritis mesin, analisis kebutuhan daya, puli-sabuk, poros, bantalan dan rangka. Hasil analisi teknik menjadi dasar bagi pembuatan gambar dan pembelian komponen untuk membuat mesin.

\section{5). Pembuatan Gambar Mesin}

Pembuatan gambar mesin didasarkan pada kriteria rancangan mesin yang telah ditetapkan. Pada kegiatan menggambar ada dua proses yang harus dikerjakan secara simultan, yaitu: analisis teknik dan menggambar. Analisis teknik adalah menghitung secara matematis beberapa komponen mesin yang digunakan dengan mengunakan data-data standar atau hasil pengukuran secara langsung. Proses menggambar merupakan visualisasi dari proses analisis teknik sehingga dihasilkan gambar yang mencerminkan bentuk mesin sesungguhnya yang akan dibuat. Disain mesin perontok sorgum disajikan pada Gambar 2.

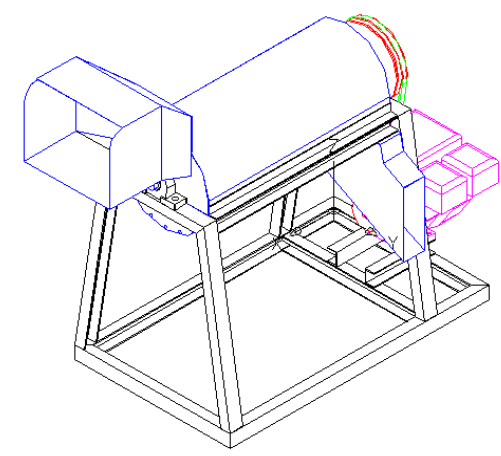

Gambar 2. Disain mesin perontok sorgum

\section{Mesin Perontok Sorgum Hasil Rancang Bangun}

Mesin perontok sorgum dikerjakan di Bengkel Logam, Jurusan Teknik dan Manajemen Industri Pertanian, Fakultas Teknologi Industri Pertanian Unpad. Pembuatan mesin berdasarkan gambar mesin, baik bentuk maupun ukurannya. Pada kenyataannya, ada komponen yang tidak sesuai baik bentuk dan ukurannya pada saat pembuatan. Hal ini disesuaikan dengan komponen yang ada di pasaran serta kemudahan dalam proses pembuatannya. Mesin perontok sorgum hasil rancang bangun dilengkapi dengan roda, hal ini bertujuan agar mesin mudah untuk digeser atau dipindahpindahkan. Hasil pembutan mesin perontok sorgum yang sudah dikerjakan disajikan pada Gambar 3.

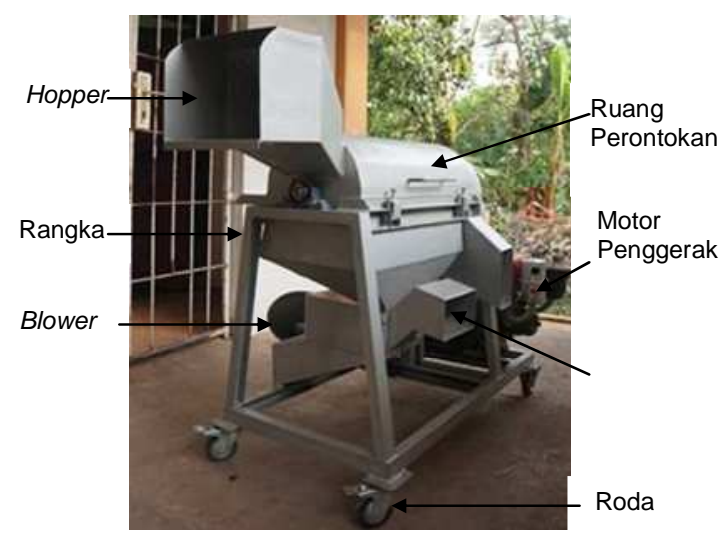

Gambar 3. Mesin perontok sorgum

Komponen utama mesin perontok sorgum terdiri dari: hopper, rangka, blower, ruang perontokkan, motor penggerak, saluran 
pengeluaran kotoran, saluran pengeluaran malai, saluran pengeluaran biji dan roda. Mesin ini digerakkan oleh motor diesel 8 PK. Motor ini menggerakkan silinder perontok di ruang penyosohan dan blower. Adapun spesifikasi mesin perontok sorgum disajikan pada Tabel 1.

Tabel 1. Spesifikasi Mesin Perontok Sorgum

\begin{tabular}{ll} 
Dimensi (PXLXT) & $\begin{array}{l}\text { Panjang }=160 \mathrm{~cm} \\
\text { Lebar }=95 \mathrm{~cm} \\
\\
\text { Tinggi }=124 \mathrm{~cm}\end{array}$ \\
\hline Motor Penggerak & Motor Diesel $8 \mathrm{PK}$ \\
\hline Kapasitas Mesin & $151,84 \mathrm{~kg} / \mathrm{jam}$ \\
\hline
\end{tabular}

\section{Pengujian Mesin}

Pengujian mesin dilakukan setelah mesin selesai dibuat. Pada pengujian dilakukan pengamatan dan pengukuran, yaitu: kinerja mesin, kapasitas mesin, dan rendemen perontokkan. Proses pengujian dan pengukuran mesin perontok disajikan pada Gambar 4. Sedangkan biji sorgum hasil perontokkan disajikan pada Gambar 5.

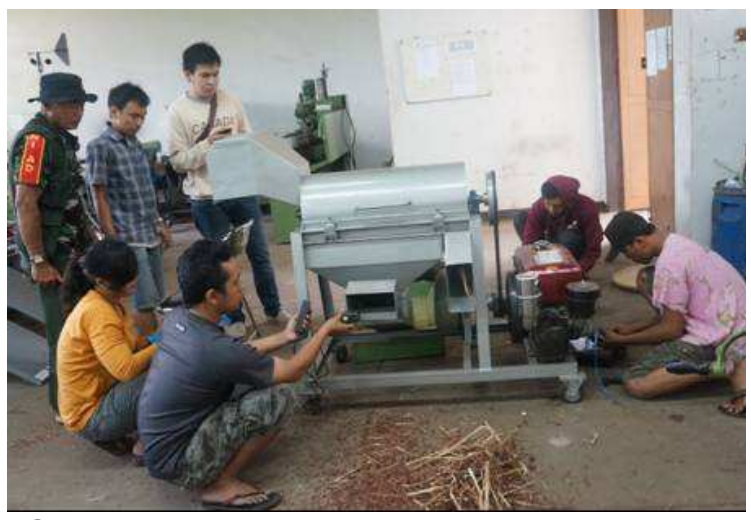

Gambar 4. Proses Pengujian dan Pengukuran

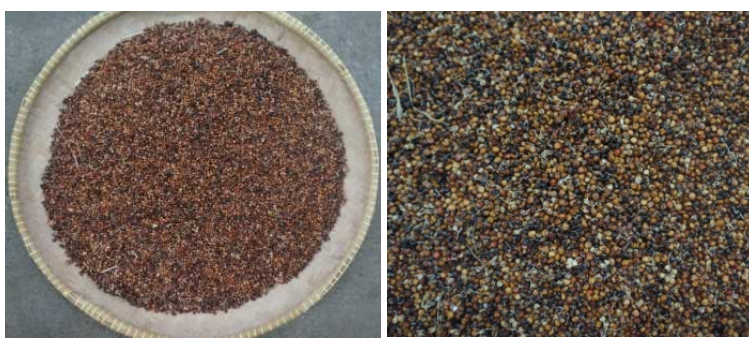

Gambar 5. Biji Sorgum Hasil Perontokkan

\section{1). Kinerja Mesin}

Pengujian mesin perontok sorgum dilakukan ketika beban kosong dan beban isi. Beban kosong yaitu mesin dinyalakan tetapi bahan tidak dimasukkan ke dalam ruang perontok. Sedangkan beban isi yaitu mesin dinyalakan kemudian malai sorgum dimasukkan untuk dirontokkan. Proses pengujian diawali dengan menimbang malai sorgum yang akan diuji. Mesin perontok dinyalakan sampai putaran silinder perontok stabil dan kemudian malai sorgum dimasukkan ke dalam hopper. Parameter yang diukur yaitu kecepatan putaran silinder, kecepatan aliran udara pada saluran pengeluaran biji dan tingkat kebisingan. Adapun hasil pengujian tersebut seperti yang disajikan pada Tabel 2. Kecepatan putar silinder perontok sekitar $671 \mathrm{rpm}$ pada saat beban kosong dan 636 pada saat beban isi. Kecepatan mengalami penurunan pada saat bahan dimasukkan ke dalam mesin. Karena terjadi gesekan antara malai sorgum yang dirontokan dengan dinding ruang perontokkan maka putaran silinder akan berkurang.

Tabel 2. Data Pengujian Mesin Perontok Sorgum

\begin{tabular}{lrr}
\hline \multicolumn{1}{c}{ Item Pengujian } & \multicolumn{1}{c}{$\begin{array}{c}\text { Beban } \\
\text { Kosong }\end{array}$} & \multicolumn{1}{c}{ Beban } \\
\hline $\begin{array}{l}\text { Kecepatan Putar } \\
\text { Silinder, RPM }\end{array}$ & 671,00 & 636,00 \\
$\begin{array}{l}\text { Kecepatan aliran } \\
\text { udara } \\
\text { m/detik blower, } \\
\text { Tingkat Kebisingan, } \\
\text { dB }\end{array}$ & 4,50 & 3,40 \\
\hline
\end{tabular}

Berdasarkan data pada Tabel 2, nilai kebisingan pada saat beban kosong sebesar 93,2 dB sedangkan pada saat beban isi sebesar $94,6 \mathrm{~dB}$. Nilai kebisingan antara beban kosong dan isi tidak berbeda jauh yaitu 1,4 dB. Nilai kebisingan meningkat ketika bahan masuk ke ruang perontokkan. Hal ini dikarenakan suara yang ditimbulkan oleh gesekan bahan yang dirontok dengan saringan. Berdasarkan nilai ambang batas kebisingan menurut KEPMENAKER No.Kep-51/Men/1999, maka waktu pengopersian mesin pengolah sorgum bagian penyosoh disarankan dibawah 1 jam untuk tetap menjaga kenyamanan operator.

\section{2). Kapasitas Aktual Mesin}

Kapasitas aktual perontokkan sorgum merupakan salah satu parameter yang diamati

50 Rancang Bangun dan Uji Kinerja Prototipe Mesin Perontok Sorgum 
dalam penelitian ini. Kapasitas aktual perontokkan dihitung dengan membandingkan berat total biji sorgum hasil perontokkan dengan lama perontokkan. Pada penelitian ini dilukan dua kali ulangan dengan masing-masing $2,92 \mathrm{~kg}$ dan $2,86 \mathrm{~kg}$. Jumlah ini kurang banyak, sehingga diperlukan pengujian lapangan pada petani atau kelompok tani sorgum dengan jumlah bahan yang banyak dan diuji secara kontinyu sehingga akan diketahui endurance mesin tersebut. Kapasitas aktual mesin perontok sorgum tersaji pada Tabel 3. dimana perhitungan kapsitas aktual dengan cara membandingkan malai sorgum yang masuk dengan biji sorgum yang keluar dari mesin perontok. Besarnya kapasitas aktual rata-rata sekitar 151,84 kg/jam. Kapasitas ini cukup besar karena ruang perontokan cukup besar sehingga dapat menampung malai sorgum lebih banyak. Rendeman perontokkan sorgum masih kecil yaitu 67,7\%. Rendemen dihitung dengan membandingkan massa malai sorgum yang masuk dengan biji sorgum hasil perontokkan.

Tabel 3. Kapasitas Aktual Mesin Perontok Sorgum

\begin{tabular}{lrrr}
\hline Parameter & Ulangan 1 & Ulangan 2 & \multicolumn{1}{c}{ Rata-rata } \\
\hline Malai & 292,000 & 286,000 & $2,890,000$
\end{tabular}

Sorgum

Masuk, kg

Biji Sorgum

Keluar, $\mathrm{kg}$

Waktu, jam

200,000

198,000

$0,01378 \quad 0,01249$

Kapasitas

$14,513,000$

$15,854,000$

aktual,

$\mathrm{kg} / \mathrm{jam}$

Rendemen

Perontokan,

$\%$

\section{KESIMPULAN DAN SARAN}

\section{Kesimpulan}

Mesin perontok sorgum berhasil dirancang bangun dengan komponen utama terdiri dari: hopper, rangka, blower, ruang perontokkan, motor penggerak, saluran pengeluaran kotoran, saluran pengeluaran malai, saluran pengeluaran biji dan roda. Spesifikasi mesin yang didesain yaitu panjang $160 \mathrm{~cm}$, lebar $95 \mathrm{~cm}$, tinggi 124 $\mathrm{cm}$, kapasiatas aktual mesin yaitu 151,84 kg/jam dan penggeraknya berupa motor diesel $8 \mathrm{HP}$. Rendemen hasil perontokan yaitu 67,7\% Data hasil pengujian mesin perontok beban isi yaitu
Colas, A. 1994. Defining Flour Quality According to Use. In Godon B., and Williem C. (Eds). Primary Cereal Processing. VCR, 452-517.

kecepatan putar silinder $636 \mathrm{rpm}$, kecepan aliran udara 3,4 m/detik dan tingkat kebisingan 94,6 dB

\section{Saran}

Perlu pengujian dalam jumlah banyak untuk menguji endurance dari mesin perontok dan perlu adanya pengujian lapangan pada petani atau kelompok tani sorgum.

\section{UCAPAN TERIMA KASIH}

Pada kesempatan ini kami ingin mengucapkan terima kasih kepada Lembaga Penelitian dan Pengabdian Masyarakat Universitas Padjadjaran melalui keputusan Rektor No. 1778/UN6.RKT/PN/2012 yang telah memberikan kesempatan dan bantuan biaya Penelitian Hibah kompetitif yang berjudul Rancang Bangun Prototipe Mesin Perontok Sorgum sehingga kegiatan ini terlaksana dengan baik.

\section{DAFTAR PUSTAKA}

Menteri Tenaga Kerja. 1999. (KEPMENAKER No. Kep-51/Men/1999). Nilai Ambang Batas Iklim Kerja (Kebisingan) . Jakarta.

0,013135 Mudjisihono, R. Dan Darmaji, D.S. 1987. Prospek kegunaan sorgum sebagai sumber pangan dan pakan. Jurnal Penelitian dan Pengembangan Pertanian VI (I): $1-5$

Suarni. 2004. Pemanfaatan Tepung Sorgum untuk Produk Olahan. Jurnal Litbang Pertanian. 23 (-4):145-151

Suhendra. 2011. Memasuki tahun 2011 Produksi Gandum Dunia Menipis, www.detik.com, diakses tanggal 24 Januari 2011.

Yusuf, A., Djoko S. 2011. Modifikasi dan Uji Kinerja Mesin Penyosoh Sorgum TEP-3. Institut Teknologi Bandung. 